Jurnal Linguistik Terapan Pascasarjana

Available online http://jurnal.unimed.ac.id/2018/index.php/JLTUnimed

\title{
TRANSLATION STRATEGIES IN TRANSLATING THE ACEHNESE PROVERBS INTO BAHASA INDONESIA
}

\author{
Bugsu Keumala Sari \\ Amrin Saragih \\ Zainuddin
}

Diterima Mei 2018; Disetujui Juni 2018; Dipublikasikan Agustus 2018

\begin{abstract}
The reserach dealt with Acehnese proverbs with the aims of this study were to (1) toinvestigate kinds of translation strategies in translating the Acehnese proverbs into Bahasa Indonesia, (2) to investigateAcehnese proverbs realized in its translationinto Bahasa Indonesia, (3) to describe the translation strategies applied in the ways they are. The research was conducted by using qualitative descriptive design. The data of this study were Acehnese proverbs and there were translated into Bahasaindonesia by Hasjim M.K. at all (1977) taken from the book entitle "Peribahasa Aceh". The results of this study showed that (1) There were three kinds of translation strategies in translating the Acehnese proverbs into Bahasa Indonesia namely exact equivalent, near equivalent, and literal meaning, (2) In realization of Acehnese proverbs there were three ways in translating proverbs namely the words following the proverb could be introduced as the meaning of the proverb, it can be replaced with an equivalent local proverb, and its non-figurative meaning could be stated straight forwardly, (3) In translating Acehnese proverbs, the translators need to know all aspects of cultural background of both languages.
\end{abstract}

Key words: Translation, Strategies, Proverbs

How to Cite: Bungsu Keumala Sari (2018).Translation Strategies in Translating the Acehnese Proverbs into Bahasa Indonesia.JurnalLinguistikTerapanPascasarjanaUnimed, 15 (2): 90-101 


\section{INTRODUCTION}

Translation is an essential process that has a key role in exchanging information, news, culture, literature and sciences among people all over the world. It is a process of changing the source text with all of its aspects semantically, syntactically, culturally, and pragmatically into a different language. Properly, most of people in another language do not master the language well. To overcome the problem in understanding other language, it is needed translation field to bridge between one communicator and others, it means translation needed to transfer the message between two different languages, so that the exchange of messages is meant to run well.

Translation is not an easy task because a translator needs to have a bilingual competence in the original language and the target language as well as knowledge of both cultures to remove the ambiguity in some texts that are needed to be translated. Differences among cultures form an obstacle for translators as they translate texts such as idioms, proverbs, and collocations.According to Newmark (1988), there are many linguistic problems that a translator faces while translating like mistakes in usage resulting from the translator's lack of competence in writing properly, wrong use of dictionaries, using literal translation or the lack of translator's common sense.

Many people need translation to do their activities in all aspects. Therefore, highly qualified translators who have good knowledge about the target language (TL) and the languages have to transform as source language (SL) are required. To produce a good translation, a qualified translator has been able to understand ideas and thought including the message expressed in the SL and representing it in the TL. As a good translator should be able to translate any kinds of translation, one of them is literary translation. Literary translation is translation of literary works such as short stories, novels, poems, proverbs, etc. It has special characteristics as literary works different from non-literary works. According to Hodges (2011), it is a translation which not only need changing words from a language to another but also needs particular manners to express the texts in target language as sense which is contained by source language text.

As one of literary translation, proverbs are crucial components of people's speech because they are fixed expressions that have meanings which cover all aspects of life. According toLitovikina (2014), they could carry themes related to women, professions and occupations, money, love, marriage, divorce, friendship, education and learning, alcohol and drugs, children and parents, taxes, God and religion, telephones, cars and computers.

Barajas (2010) states that the shapes of proverbs are important for grasping the social construction of their meaning because they are not made of one word and they have specific forms that distinguish them from any segment of the language. Therefore, translators should be aware of shapes of proverbs when translating proverbs into their closest equivalence in the target language TL 
because there are proverbs which contain some cultural aspects in the source language SL that can't be found in the target culture.

Proverbs often referred to as "wise words" or "old sayings". They are called wise words simply because they carry wisdom and are usually used by wise members of the society in their formal speech. They are called old sayings since they are often heard from the mouths of the elders and because they have usually existed for as long as the people of a society can remember. Unlike books, paintings, poems and many other intellectual and artistic creations, proverbs do not carry any intellectual or artistic property rights. It is difficult to prove who initially created them or when a particular proverb was created. It can be said that proverbs belong to the people who own the language and its culture.

Proverbs are found in every language as a different way of saying something with certain implicit meanings. People use proverbs to express ideas, opinions and emotions that they have toward their culture, their society and their surroundings. In most traditional societies, proverbs are one of the elements that shape the culture and history that have mostly been transferred orally from generation to generation (Omolewa, 2007: 294).

As one of literary translation, Acehnese proverbs was translated into Bahasa Indonesia in order to make the proverbs can be understood and used not only in the Acehnese people who can speak Acehnese language, but also by other communities who cannot speak Acehnese language. The book of Acehnese proverbs written down in Acehnese language and translated into Indonesian by Hasjim M.K. at al (1977) is entitled Peribahasa Aceh. It is not easy to translate Acehnese proverbs into Bahasa Indonesia, thus, to bridge two languages; the translators should have particular qualities to get good product.

The Acehnese proverbs consist of norms or values in lives to maintain by members as the source of national and regional culture. It is the rule to guide and control its members about what is considered proper or improper which is contain of wisdom, knowledge and truth. Therefore one of the way to maintain and develop Acehnese proverbs are by translating into another languages in order to make it understood by other communities who cannot speak Acehnese language.

Properly, it is not easy to translate Acehnese proverbs into target language. Because translation which not only need changing words from a language to another but also needs particular manners to express the texts in target language as sense which is contained by source language text in order to understood other people who can not speak Acehnese. Because, one of the main problems in the process of translating Acehnese proverbs that include the idiomatic elements related to the culture and individuals' values in the society which is idiomatic expressions are included in this group. Therefore a translator needs strategies in translating Acehnese proverbs into Bahasa Indonesia. 
According to Newmark (1988: 28) stated that in translating idiomatic into idiomatic language, it is particularly difficult to match equivalence of meaning with equivalence of frequency. He stated that the main problems, a translator faces, are not grammatical but lexical, i.e. words, collocations, and fixed phrases or idioms. In addition, Baker (1992: 65) stated that the main problems that idiomatic and fixed expressions pose in translation relate to two main areas: the ability to recognize and interpret an idiom correctly and the difficulties in rendering various aspects of meaning that an idiom or a fixed expression conveys into the target language.

Therefore, the translators must be familiar with the strategies of translation in general and translating proverbs in particular. According to Lorscher (1996) translation strategy is "a conceivably intentional procedure to solve a problem which a translator faces when translating a text component from one language into another". It is clear from this definition that every translator should have a prior knowledge of translation strategies theoretically and practically to translate properly. Translating proverbs requires knowledge in both languages, their cultures and knowledge in strategies that are suitable for rendering the intended meaning as well. Strategies are necessary because they usually enable translators to overcome difficulties that they might encounter in the process of translation.

Besides, According to Beekman and Callow (1974: 139) there are three ways to translate the proverbs as follows (1) the words following the proverb could be introduced as the meaning of the proverb, (2) it can be replaced with an equivalent local proverb; and (3) its nonfigurative meaning could be stated straight forward.

Based on prior observation, the researcher found some preliminary data which is the translator translated Acehnese proverbs into Bahasa Indonesia as the following

\section{SL:lagèelimpeuen lam sapaibajèe}

TL: musuh yang tidakdiketahui yang selaludekatdengankita, padasuatu masadapatdenganmudahmembinasakankita. (unknown enemy that always near with us, one day she or he will kill us).

This proverb means "a snake in the grass", according to Beekman (1974), one of the way in translating proverb it can be replaced with an equivalent local proverb. It can be seen in TL, the translator translate into "musuh yang tidakdiketahui yang selaludekatdengankita, padasuatumasadapatdenganmudahmembinasakankita", the message conveyed inappropriate in the target language and many errors in the selection or use of the term. The researcher assumes that it is appropriate if the translator translated into "musuhdalamselimut". 
In addition, Another one can be seen in the following that taken from the book "PribahasaAceh "written by Hasjim M.K. at al (1977).

\section{SL: Sibakgeutak, siplóhbakreuhah}

\section{TL:Mengerjakansesuatupekerjaan, beberapahalsekaligusterselesaikan.}

(doing one thing, but already finishing two or three thing)

The translation above is translated by introduce the meaning of proverbs without replaced with an equivalent local proverb. The researcher assumes that it is appropriate if the translator translated into "Sekalimendayungduatiga pula tercapai" or "one short two birds"

Being a good translators, they have to know strategies in translating proverbs well in order to make the sense to the reader or listener, as Larson (1984:116) stated that translator needs to develop a sensitivity to the use of proverbs in the receptor language and use them naturally to make the translation lively and keep the style of the source language. When the SL and the TL are widely different in structure and cultural background, there cannot be an exactly transferred from the SL into the TL. To overcome the differences in characteristics of these languages, the translator is required to understand the structure and culture of both languages. It can be said that translation is a complicated process encompassing both linguistic and non-linguistic problems.

Therefore, in translating proverb, a good translator should understand not only the language but also the culture of both, the SL and the TL. Because the translator plays an important role to deliver message well based on the consideration about the appropriate lexical without changing the meaning, and knowing well about both of culture.

Based on the description above, then it is considered to analyze translation strategies in translating the Acehnese proverbs into Bahasa Indonesia based on the book "Peribahasa Aceh" written by Hasjim M.K. et al. There are some strategies in translating SL to TL, but the researcher only focus on translation strategies proposed by Gorjian (1996), and realization of proverbs in its translation by Beekman and Callow (1974).

\section{RESEARCH METHOD}

The study conducted by applying qualitative research, according to Bogdan and Biklen (1992) stated that qualitative research is descriptive which means what is going on and what data shows. Qualitative means to find out how a theory works in different phenomena ands data collected are in the form of word rather than numbers. Moreover, Baverley (2009:6) stated that qualitative studies behavior in natural setting or uses people's accounts as data; usually no manipulation of the variables. 
The research method in this study used descriptive research, according to Ary (1979:295) descriptive research studies are designed to obtain information concerning the current status of phenomena. They are directed toward determining the nature of a situation as it exists at the time of the study. It means that descriptive qualitative is designed or the natural setting as the direct source of data. In line with this study, it described the translation strategies in translating Acehnese proverbs into Bahasa Indonesia.

\section{FINDINGS AND DISCUSSIONS}

Based on the result of the data analysis, the findings of this study formulated as the following.

(1) In translating Acehnese proverbs, there were three kinds of translation strategies applied by translator based on Gorjian's theory, namely exact equivalent, near equivalent, and literal meaning. Besides, based on three kinds of translation strategies found in this study by refer to Gorjian' theory, there were some translations of proverbs that can not be translated by applying those strategies. In keeping sense of language and the acceptable meaning, the other strategies should be applied in translating the Acehnese proverbs, namely description translation which is the translators describe and explain the terms in SL when there is no appropriate words can be found in the TL. In overall, there were four kinds of translation strategies in translating the Acehnese proverbs into Bahasa Indonesia, namely exact equivalent, near equivalent, literal meaning, and description translation.

(2) In realization of Acehnese proverbs there are three ways that can be applied in translating Acehnese proverbs based on Beekman and Callow's theory, namely the words following the proverb could be introduced as the meaning of the proverb; it can be replaced with an equivalent local proverb; and its non-figurative meaning could be stated straight forwardly.

(3) In translating proverbs, especially Acehnese proverbs, the translators should know SL/TL culture and its relations to their religion, customs, ceremonies, languages, geographical places, climate and all aspects of cultural background and literature heritage of both languages in translation.

Dealing with the research findings above, hence it is vitality important to match it with the theories to highlight whether these findings are constrastive or in line. The discussion to the kinds of translation strategies in translating proverbs are forwarded. The resercher investigates the findings of the kinds of translation strategies in translating the Acehnese proverbs into Bahasa Indonesia and the theories. Furthermore, the investigation of whether the findings are in constrastive to the relevant studies, there was a gap between fact and theory.There are many researchers on translationstrategies in translating proverbs, the 
numerous studies have described and rised many issues on the different strategies in their ways in translating proverbs.

Dweik and Talji (2016) conducted the study about strategies for translating proverbs from english into arabic which is to explore strategies used by Jordanian novice translators when rendering proverbs from English into Arabic. The study revealed that the translation strategies manipulated when rendering proverbs from English into Arabic were cultural equivalent; literal; paraphrasing, and glossing.

Putranti (2015) investigated about synonym translation to overcome problems of SL and TL cultural differences. This concept implies translators' efforts to maintain message equivalence. A common problem found intranslation is loss and gain of meaning. To overcome translation problems related to loss and gain ofmeaning as a result cultural differences, various translation strategy could be applied. Synonymyis one of many translation strategy commonly used. This strategy is applied when a translationis not the first literal translation of the SL text. This strategy is usually chosen when translatorscould not find the one-to-one substitute in the TL.

In addition, Aliakbar (2012) in his research described about translation of idioms and proverbs, despite the extensive research on translation and challenges on translation of figurative language, in particular idioms and proverbs. The findings reveal that translation by paraphrasing and replacing proverb with an equivalent local proverb at were applied in translation of idioms and proverbs respectively. It also shows that the translator translated the idioms and proverbs in an idiomatic and natural way.

The various application of translation strategies, it is just goes to one goal, namely the accruacity to find a good translation product. The accuracy of translation process needs to avoid a worst translation product distortion. Eventhough the lost of meaning from source language in translation text, for instance it occurs pharaphasing by addition, deletion, and hide meaning from source language into target language.Besides, to produce a good translation, namely by creating the dynamic equivalence meaning, it will created a similar meaning (Nida, 1982:73) and it is also stresses by Catford (1965:21) explains that the central problem of 
translation practice is that of finding the target language translation equivalence (ST and TL) then produce and create a right translation, acceptable and equivalent based on principles of translation.

In this research findings, it is showed that the applying strategies included excat equivalent (strong version), near equivalent (moderate version), and literal meaning (weak version). The analysis detrmined that the frequently used in translating the Acehnese proverbs into Bahasa Indonesia is exact equivalent (strong version) because based on observation the meaning in TL is familiar for members in society. So, the reader easier to catch the message that delivered by translator. Besides, in exact equivalent that the translator shared the appropriate lexical, semantics and conceptual properties existed in both SL and TL. Therefore applying this strategy was the frequently used among the three strategies propsed by Gorjian. (see table 4.1).

In this study, the researcher has reported significant differences in translating the Acehnese proverbs, which is the researcher found the three strategies above do not enough in translating the Acehnese proverbs, the researcher found the new one invention was desciption translation. It is used when the translator feel difficult in finding the synonym of the SL, which the SL does not know the appropriate lexical or term in TL, therefore, the translator forced to make the description that contains the meaning of the word in a statement. On the other hand, it is applied to describe and explain the terms in SL into the TL For instance:

SL:Aceh Seuramoe Makah, Aceh Darussalam, Aceh Tanoh reuncöng

TL: Daerah Aceh terkenal dengan beberapa nama, misalnya Aceh Serambi Mekah. Nama ini menunjukkan bahwa, penduduknya taat kepada agamanya. Aceh Darussalam, bahwa Aceh itu terkenal daerah yang aman dan damai. Aceh Tanah Rencong menunjukkan bahwa suku Aceh terkenal keberaniannya dan senjata rakyat umum adalah rencong

Based on datum above, it is show that the translator add some information to introduce Acehnese culture by giving description in a statement form. Besides, it is applying because the translator do not find any appropriate words or terms of SL. Therefore description translation should be applied in translating the Acehnese proverbs into Bahasa Indonesia in order to describe and explain the terms in SL. This strategy replace a term or expression with 
a description of its form or/and function in the ST message to make it clear in the TL. Thus, the translator forced to make the description that contains the meaning of the word in a statement.

\section{CONCLUSIONS}

After analyzed data based on the previous chapter, the study made it possible to arrive at the following conclusions.

(4) There are four kinds of translation strategies in translating Acehnese proverbs, exact equivalent, near equivalent, literal meaning, and description translation.

(5) In realization of Acehnese proverbs there are three ways that can be applied in this study, they are the words following the proverb could be introduced as the meaning of the proverb; it can be replaced with an equivalent local proverb; and its non-figurative meaning could be stated straight forwardly.

(6) In translating proverbs, especially Acehnese proverbs, the translators should know SL/TL culture and its relations to their religion, customs, ceremonies, languages, geographical places, climate and all aspects of cultural background and literature heritage of both languages.

\section{REFERENCES}

Akbari, M. 2013 Strategies for Translating Idioms. Iran: Islamic Azad University, $\quad$ Science and Research, ISSN1925-931X, Journal of Academic and Applied Studies, Vol. 3(8), pp. 3241 Available online @ www.academians.org

Ary, D., Jacobs, L.C., and Razaviyah, A, 1979.Introduction to Research in Education ( $2^{\text {nd }}$ Edition). New York: Holt, Rinehart and Winston

Aulia, D. 2012. The Application of Translation Strategies to Cope With Equivalence Problems in Translating Texts. ISSN: 2252 - 4797 Volume 1 Journal Polingua Scientific Journal of Linguistic, Literature and Education English Department, State Polytechnic of Padang

Bakar, A. M. K.. et al. 1985. Kamus Aceh Indonesia. Jakarta: Pusat Pembinaan dan Pengembangan Bahasa Departemen Pendidikan dan Kebudayaan

Baker, M. 2006. In Other Words: A Course Book on Translation. London \& New $\quad$ York: Routledge.

Bell, R. T. 1991. Translation and Translating: Theory and Practice, London: $\quad$ Longman 
Beekman, J, and John, C. 1974.Translating the Word of God. Grand Rapids, MI: Zondervan

Brislin, R. W. 1976. Translation: Application and Research. New York: Gardner Press Inc.

Brunvand, J, H. 1986 The Study of American Folklore: An Introduction. $3^{\text {rd }} \quad$ Edition. New York: Norton

Bogdan, R. and Biklen, S.K. 1992. Qualitative Research for Education: An Introduction to Theory and Method $2^{\text {nd }}$ Ed. Boston: allyn and Bacon

Catford, J. C. 1965. A Linguistic Theory of Translation. London: Oxford University Press.

Dabaghi, Azizollah, and friends. 2010. Proverbs from the Viewpoint of Translation. ISSN 17984769 Journal of Language Teaching and Research, Vol. 1, No. 6, pp. 807-814, November 2010. ACADEMY PUBLISHER Manufactured in Finland

Dweik, B and Thalji, M. 2016 Strategies for Translating Proverbs from English Into Arabic. Jordan: Middle East University,ISSN: 2223-9553 Vol. 7(2), Academic Research International, Faculty of Arts and Sciences.

Farahani, A. 2012.The Naturalness in Translation of Idioms and Proverbs:A Persian Translation of Pinocchio. Vol. 3 (6) (pp.17-22), Journal of Language and Translation, University South Tehran Branch

Ghazala, H. 1995.Translation as Problems and Solutions. $4^{\text {th }}$ Edition. Syria: Dar El-Kalem El-Arabi

Gorjian, B. 1996. A survey of translated Holy Qur'an into English. Afarinsh

Gorjian, B., \& Molonia, S. 2005. The ways to know life: Translated maxims. Tehran: Rahnama.

Hassan, M and Farhan, M. Strategies of Translating Idioms. 2014Lahore, Pakistan: University of South Asia, ISSN 2055-6071Vol.2, No.3, pp. 14- 29, Published by European Centre for Research Training and Development UK (www.eajournal.org)

Hasyim, M. K.. et al. 1977. Peribahasa Aceh Daerah Istimewa Aceh. Banda $\quad$ Aceh: Dinas Pendidikan Dasar dan Kebudayaan.

Hatim, B., \& Mason, I. 1990. Discourse and the translator. London: Longman.

Hatim\&Munday. 2004. Translation, An Advanced Resource Book. London: $\quad$ Routledge.

Larson, M. L. 1984. Meaning-Based Translation: A Guide to Cross-Language Equivalence. Lanham Md: University Press of America.

Larson, M. L. 1997. Meaning Based Translation: A Guide to Cross Language Equivalence. Lanham: University of America.

Lazar, G. 2003. Meaning and Metaphor. Cambridge: Cambridge University Press

Lincoln, YS. \& Guba, EG. 1985. Naturalistic Inquiry. Newbury Park, CA: Sage Publications. 
Lorscher, W. 1996. A psycho linguistic analysis of translation processes. Meta, XLI,1, 26-32. Retrieved November8, 2016, Online http://erudit.org/revue/meta/2004/v41/n1/029689ar.html

McMillan, J, H. 1992. Educational Research: Fundamental for the Consumer. New York: Congress Cataloging

Miles, M.B and Huberman, A.M, \& Saldana. 2014. Qualitative Data Analysis: A Method of Source Book. $3{ }^{\text {rd }}$ Edition.USA: Sage Publication

Mollanazar, H. 2001. Principles and methodology of translation. Tehran: SAMT.

Munday, J. 2001. Introducing Translation Studies, London: Routledge.

Nababan, M. 2003. TeoriPenerjemahanBahasaInggris, Yogyakarta: Pustaka Pelajar

Nida, E. A. and C.R.Taber.1982.The Theory and Practice of Translation, $\quad$ Leiden:E. J.Brill.

Newmark, P. 1988. A Textbook of Translation. London: Prentice Hall International.

Nord, C. 1991. Text analysis in translation: Theory, methodology and didactic application of a model for translation-oriented text analysis. Amsterdam: Rodopi.

Norman, I.2011. HadihMaja (FilosofiHidup Orang Aceh), Banda Aceh : Bandar Publish.

Panou, D. 2013. Equivalence in Translation Theories: A Critical Evaluation. UK: Department of Education, University of Leicester. ISSN 1799-2591 Theory and Practice in Language Studies, Vol. 3, No. 1, pp. 1-6, January 2013 @ 2013 Academy Publisher Manufactured in Finland.

Putranti, A. 2015.Synonymy: A Translation Procedure to Overcome Problems of SL and TL Cultural Differences.Vol. 15 (2) English Letters Department, UniversitasSanata Dharma

Robinson, D. 1997. Becoming a translator: An accelerated course.London: $\quad$ Routledge.

Sadhegi, B and Farjad, A. 2014.Translation Strategies of English Idioms by EFL Learners.EISSN: 2289-2737 \& ISSN: 2289-3245 volume 6 (3), July 2014; $\quad 247-$ 259International Journal of Language Learning and Applied Linguistics World(IJLLALW), Department of Foreign Languages, College of Humanities, Takestan Branch, Islamic Azad University, Takestan, Iran

Sag, I. T. Baldwin, F. Bond, A. Copestake, and D. Flickinger. 2001. Multiword expressions: $\quad$ a pain in the neck for NLP. Lin GO Working Paper No. $2001-03$.

Shirley, A. 1984. The perception of proverbiality. 1:1-38

Sudaryat, Y. 2009. MaknadalamWacana.Bandung: CV YramaWidya

Sugiyono. 2013. MetodePenelitianKuantitatif, Kualitatifdan $R \& D$. Bandung: $\quad$ Alfabeta

Venuti, L. 1995. The Translator's Invisibility: A History of Translation. London \& New York: Routledge 
Wilss, W. 1982.The Science of Translation. Stuttgart: Gunter Narrverlag Tubingen.

Wolfgang, M.2004. Proverbs: A Handbook. Westport, Connecticut:

Greenwood Press. 